\title{
THE EFFECT OF LOCUS OF EXTERNAL INTERNAL CONTROL, FINANCIAL ATTITUDE, POCKET MONEY AND LIFESTYLE ON THE USE OF E-MONEY
}

\author{
Alya Nurul Anggari \\ Program Studi Akuntansi Universitas Negeri Yogyakarta \\ alyanurulanggari28@gmail.com \\ Patriani Wahyu Dewanti \\ Program Studi Akuntansi Universitas Negeri Yogyakarta \\ patriani_wd@uny.ac.id
}

\begin{abstract}
The Effect of Locus of External and Internal Control, Financial Attitude, Pocket Money and Lifestyle on The Use of E-Money. This study aims to determine the influence of Locus of external internal control, financial attitude, pocket money and lifestyle on the use of e-money in accounting students in Yogyakarta. The population is all students of accounting study programs that are still active in 4 universities in Yogyakarta with a total of 200 respondents and 134 is a sample of this research. This study was conducted by questionnaires using multiple liner regression tests. The results showed that the locus of external control and lifestyle positively influenced the locus of internal control, financial attitude and pocket money of students had no effect on the use of e-money in accounting students of the University in Yogyakarta.
\end{abstract}

Keywords: Locus of control external and internal, Financial attitude, Pocket Money, Lifestyle, E- Money

Abstrak: Pengaruh Locus Of Control Eksternal Dan Internal, Financial Attitude, Uang Saku, Dan Lifestyle Terhadap Penggunaan E-Money. Penelitian ini bertujuan untuk mengetahui pengaruhl Locus of control external dan internal, financial attitude, uang saku dan lifestyle terhadap penggunaan e-money pada mahasiswa akuntansi di Yogyakarta. Populasi dari penelitian ini adalah mahasiswa program studi akuntansi aktif di 4 universitas di Yogyakarta dengan total 200 orang dan 134 merupakan sample penelitian. Penelitian ini dilakukan dengan menyebarkan kuesioner online dengan uji regresi liner berganda. Hasil penelitian menunjukkan locus of control external dan lifestyle berpengaruh positif sedangkan locus of control internal, financial attitude dan uang saku tidak berpengaruh terhadap penggunaan e-money pada mahasiswa akuntansi Universitas di Yogyakarta.

Kata Kunci : Locus of control external dan internal, Financial attitude, Uang Saku, Lifestyle, E- Money

\section{INTRODUCTION}

Rapid technological advances and innovations present a variety of options in conducting financial transactions with the aim of ease and effectiveness of users. Millennials or commonly called
iGeneration is the generation of users with the largest percentage specifically on cashless financial services in a decade. When the sale and purchase transaction has been provided shopping applications such as Shope, Lazada, JD.id, 


\section{Nominal: Barometer Riset Akuntansi dan Manajemen \\ P-ISSN: 2303-2065 E-ISSN: 2502-5430 \\ Volume 10 No 2 (2021)}

and others that make it easier for us to buy the desired goods without the need to leave the house because the goods that we have ordered will go directly to the house with a set time. Online shopping payment can be done by transfer via internet banking, mbanking, sms banking.

E-money or Electronic Money is money used in internet transactions involving computer networks or PCs that have stored value and have undergone the evolution of data placed in a container. This service is an alternative in the financial world that is very potential in improving financial inclusion, many companies in the field of telecommunications and banking are competing in creating e-money services even for now followed by startup companies in the field of fintech such as Tokopedia, gopay, ovo etc. Head of the Communication Department, Onny Widjanarko explained that Accumulated January-August 2020, the value of electronic money transactions worth $\mathrm{Rp}$ 126.95 trillion. This value increased by $31 \%$ when compared to the average transaction in 2019 with a value of Rp 12.09 trillion per month. With this total value of electronic transactions throughout the 8 months has presented $87 \%$ of the total accumulated transaction value in 2019 .

The features of the services provided are varied, centralized and always up to date. This is in accordance with research conducted by which states that students often do not have responsibility in their financial resources and management carefully, Financial decision making on the basis of thought is called financial attitude. Financial attitude is a state, mind, opinion and assessment regarding finances. Someone with a high level of financial attitude will have a good mindset about money so that it can manage finances well.

For example, when someone is buying an item that gets a buy offer 1 get 2 , in general the nature of a person will be divided into two, namely tempted and bought the item or ignore it, that's when the financial attitude of a person, when someone ignores the offer this explains that the person's financial attitude is high and vice versa, if someone is tempted and shopping on the basis of the offer this explains that the financial attitude of the person is low. Whereas in each of its financial activities, the behavior of controlling spending planning is called the locus of control. Locus of control is the belief in each individual regarding the determining source of his actions with the results received. Besides locus of control, financial attitude, pocket money, lifestyle can also affect students in using E- 


\section{Nominal: Barometer Riset Akuntansi dan Manajemen \\ P-ISSN: 2303-2065 E-ISSN: 2502-5430 \\ Volume 10 No 2 (2021)}

money. Differences in students addressing the lifestyle in their environment become the main factor in the level of use of emoney. Students who are apathetic in the trend in their environment will be less in using e-money, while openminded and open students of technology will be more often to use e-money. According to Sathish \& Rajamohan lifestyle shows how a person's action patterns in their spending money and how they allocate their time that distinguishes one person from another. Krisdiantoro, Susanto \& Maryati explained that lifestyle is formed from 3 basic so-called AIO theory that contains several questions describing the activities, interests, and opinions of consumers Based on a survey conducted by Riko Abdurrahman, President Director of PT Visa Worldwide Indonesia shows that "the public will remain consistent with their lifestyle regarding how to pay using electronic payments for daily activities even if the Covid-19 emergency period ends. From the results of this survey is proven that people have a lifestyle that follows every technology, trend or every development of the environment.

\section{LITERATURE REVIEW}

\section{Theory Planned of Behavior}

Theory of planned behavior is a theory that focuses on individual behavior and belief that behaviors and events are under the control of individual consciousness. Suppose on opportunity and opportunity taking (Ajzen, 2005). This theory describes the relationship between beliefs, attitudes, wills or intense, and behaviors of each individual. In this case theory planned of behavior can describe how student in four university calculate their activities on using e-money likes buying product when this product got discount before.

\section{E-money}

Electronic money (e-money) is also interpreted as an electronic means of payment that involves a computer network that has a stored value (stored value) or prepaid (prepaid) where the nominal money is stored in electronic media owned by a person, this nominal value will be reduced when used (Ardiyanti, 2015).

\section{The Effect of Locus of External Control on the Use of E-money}

The concept of locus of control was first put forward by Rotter in 1996 who is a social learning theorist. Locus of control can be interpreted as a person's view of an event whether or not he or she can control the events that occur in him (Rotter J. B., 1966).

Locus of control according to Kreitner and Kinicki (2001) consists of two constructions, namely internal and external, where if a person who believes that what is 
happening is always in his control and always takes a role and is responsible in every decision making included in the internal locus of control, while a person who believes that events in his life are out of his control belongs to the external locus of control (Kreitner, 2001).

In this case associated with the locus of external control with the use of e-money lies in the belief of students or individuals in general against the election in the use of e-money. Individuals who have a weak external locus of control will still choose emoney transactions, in this case in case of failure such as waste of the budget that has been set whether the individual will blame others for the level of use of e-money that is done regularly that indirectly made an increase in use of e-money. Similarly, if students feel that using e-money becomes easier or more budgeted, they feel confident in their choice to follow factors from outside them. This will affect the attitude of students in the future in utilizing and using e-money because the results that will be experienced as a result of use for some time will affect students' confidence in the use of e-money. Thus locus of control external have a positively impact on the use emoney

H1: Locus of external control positively affects the use of e-money in students of Accounting study program of University in Yogyakarta.

\section{The Effect of Locus of Internal Control on the Use of E-money}

The internal locus of control assumes that they are capable of controlling and responsible for the amplifiers it receives (Rotter J. B., 1972). Levenson (1981) said that the locus of control is the belief of each individual to the main cause of behavior and activity or attitude of events or events in his life that stem from inside or in himself or outside factors him self

In this case associated with the locus of internal control with the use of e-money lies in the belief of students or individuals in general against the election in the use of emoney. Individuals who have a weak internal locus of control will still choose emoney transactions, in this case in case of failure such as waste of the budget that has been set whether the individual will blame himself for the level of use of e-money conducted on a regular basis under controll.. This will affect the attitude of students in the future in utilizing and using e-money because the results that will be experienced as a result of use for some time will affect students' confidence in the use of e-money. Thus locus of control internal have a negative impact on the use e-money $\mathrm{H} 2$ : Locus of internal control negatively affects the use of e-money in students of 
Accounting courses of the University of Yogyakarta.

\section{The Effect of Financial Attitude on the Use of E-money}

Financial attitude was first stated by Pankow (2003) who stated that financial attitude is an attitude, circumstance or opinion of one's life (Pankow, 2003). Attitude is how a person responds to an object, an individual, or responds to his or her financial situation (Robbins, 2008). Each person's financial attitude will help and influence individuals to manage and manage their finances. Such behavior can be in the form of budgeting, management, and decision making on investment, saving, and spending money. In this case it is associated with financial attitude with the use of e-money because in the use of emoney will have a positive and negative impact, so a student especially regional students / costs will take a certain attitude to overcome the various impacts of the use of e-money. Thus financial attitude have a negative impact on the use e-money

H3: Financial attitude negatively affects the use of e-money in students of Accounting program of The University in Yogyakarta.

The Effect of Pocket Money on the Use of E-money

Joceylin (2011:10) states that pocket money is a form of responsibility, so it needs to be accompanied by the planting of value for money, so that the money provided by parents with the planning of the money is used for transportation or savings. Pocket money here is money given to meet the needs of students, therefore it must be managed well so as not to overdo it especially when using e-money. Because pocket money is the main subject of the use of e-money, then in its utilization has a good and bad impact on an individual's budget if he cannot predict the needs and usage of e-money. If the use of e-money adversely affects financial problems, namely waste, budget instability, mistakes will be priorities etc., financial attitude in this study will discuss how students respond to problems that may be caused by the use of e-money. Thus pocket money have a positive impact on the use e-money H4: Pocket Money positively affects the use of e-money in students of Accounting courses at the University of Yogyakarta.

The Effect of Lifestyle on the Use of Emoney

Kanserina (2015) states that lifestyle is a person's lifestyle presented with activities, interests and opinions, in essence lifestyle can be seen from the routine activities carried out and what one thinks about the surroundings and how concerned the person is. In this topic lifestyle is more about one's behavior or activity in spending money. modernization and technology 


\section{Nominal: Barometer Riset Akuntansi dan Manajemen \\ P-ISSN: 2303-2065 E-ISSN: 2502-5430 \\ Volume 10 No 2 (2021)}

carried out through action, interest and behavior in human lifestyle affects how humans, especially students, use money and how they use it. How students follow their lifestyle affects the intensity in the use of e-money, for students who are not easily interested in the lifestyle in the environment and its surroundings then they will still buy goods according to their needs and still control their spending because it rarely uses e-money for things outside the budget but students who are always tempted by the lifestyle of people or the environment will still use e-money to transact unnecessary things and only desire, the result of its use will be increasing followed by uncontrolled pocket money or budget. And there is a discount on fashion as an example is a form of financial attitude in the use of e-money in addition to the level of lifestyle of the student. Thus lifestyle have a positive impact in the use of e-money.

H5: Lifestyle positively affects the use of emoney in students of Accounting courses at the University of Yogyakarta.

\section{RESEARCH METHOD}

\section{ResearchDesign}

This research is quantitative research. Quantitative research is research conducted with an inductive deductive approach that departs from a theoretical framework, the idea of experts, or the understanding of researchers based on their experience and then developed into problems and solutions proposed to obtain justification in the form of empirical data support in the field (Sugiyono, 2016).

\section{Place and Time of Research}

This research was conducted in Yogyakarta by involving accounting students as respondents at four universities in Yogyakarta, namely Yogyakarta State University (UNY), Indonesian Islamic University (UII), STIE YKPN and Yogyakarta Veterans National Development University (UPN). The selection of students as respondents is because students are active users of emoney. The research was conducted in January - February 2021.

\section{Population and Sample of Research}

The population in this study is accounting students who are active students of four universities domiciled in Jogja. The selection of the university is due to the distribution of research directed at two major public universities and two large private universities that are expected to represent universities in Yogyakarta.

The sample in this research use a purposive sampling. Purposive sampling is a sampling technique of population members with certain considerations or criteria. The criteria of this research sample are accounting students who have studied 


\section{Nominal: Barometer Riset Akuntansi dan Manajemen \\ P-ISSN: 2303-2065 E-ISSN: 2502-5430 \\ Volume 10 No 2 (2021)}

accounting behavior and are users of emoney. In the distribution of samples is carried out with snowball techniques where samples are obtained through one respondent to another to get answers from respondents.

\section{Definition of Variable Operational}

\section{Dependent Variables}

E-money

Bank Indonesia Regulation article 1 paragraph (3) Number 16/8/PBI/2014 concerning amendments to Bank Indonesia Regulation No. 11/12/PBI/2009 concerning electronic money, Electronic money (emoney) as a means of electronic payment obtained through the deposit of a certain amount of money to the issuer in advance either directly or from agents- issuers or by debiting an account at the bank, and the value of the money will be put into the value of money in e-money in rupiah units. Locus of External and Internal Control

Locus of control can be interpreted as a person's view of an event whether or not he or she can control the events that occur to him (Rotter J. B., 1966). This variable will show how much control an accounting student has in utilizing e-money. Here researchers examine whether the locus of external control positively affect and the locus of internal control negatively affects the level of use of e-money.
Financial Attitude

According to Pankow (2012), financial attitude is a person's circumstances, judgments, and thoughts on money applied and applied that occur in his life into a certain attitude. In this research financial attitude as a free variable (X2) which becomes one of the influences in the use of e-money periodically in daily life that indirectly becomes a change in the direction of behavior and financial attitude of accountant students in DIY

Pocket Money

Widya (2014) explained that pocket money is money that is not the same as snack money, pocket money is more to the money to meet the daily needs of each individual. Pocket money in this study became a free variable (X3) to examine whether there is a positive influence of pocket money to the use of e-money in daily habits. This study will measure the level of need and influence of pocket money on the use of e-money it self Lifestyle

Lifestyle is a person's lifestyle that is presented with activities, interests and opinions, in essence lifestyle can be seen from the routine activities carried out and what one thinks about the things around him and how concerned the person is (Kanserina, 2015). Lifestyle in this study became a free variable $(\mathrm{X} 4)$ to examine 
whether the lifestyle owned by students will have a positive or negative effect on the use of e-money.

The lifestyle owned by students certainly differs depending on how the environment affects it, this lifestyle difference will affect the level of use of emoney.

\section{Data Collection Techniques}

The data used in this study is primary data obtained directly from the research object. Primary data refers to information obtained first-hand by researchers relating to interest variables for the specific purpose of the study (Sekaran, 2017). Data collection techniques in this study using questionnaires that are distributed directly through google form.

\section{Data Analysis Techniques}

The data analysis techniques were descriptive statistics analysis, classic assumption test, and multiple linear regression analysis.

\section{RESULT AND DISCUSSION}

\section{Description of Research Data}

Respondents in this study were students of accounting study program at four universities of Yogyakarta totaling 134 students who have been or are attending behavioral accounting courses. The questionnaire was distributed online using google form to 200 accounting students. Of the 200 data obtained, 44 were used for validity and reliability tests, 28 were not used because they did not meet the criteria

\section{Descriptive Characteristics Analysis}

Based of total 134 respondents, the most age respondents from this study were respondents with the age of 21 years. the respondent gender with the largest number are female with a total of 91 people or as many as $68 \%$. Yogyakarta State University (UNY) were the most respondents who filled out questionnaires with a total of 63 respondents or as many as $47 \%$ and Emoney is most often used by respondents is Gopay with the number of 92 people or as much as $68 \%$, the second type is OVO with the number of 91 people or as much as $67 \%$.

\section{Descriptive Statistics Analysis}

E-money

E-money (Y) that had been measured using online questionnaires or google forms with 7 question items. Descriptive analysis of emoney variables aims to group the results of respondents' answers to questionnaires related to e-money with the highest value result (max) of 40, the lowest value (min)of 11, the average value (mean) 28.30 and standard deviation of 5,665 .

Locus of External Control

Locus of external control (X1.1) which had been measured using an online 


\section{Nominal: Barometer Riset Akuntansi dan Manajemen \\ P-ISSN: 2303-2065 E-ISSN: 2502-5430 \\ Volume 10 No 2 (2021)}

questionnaire or google form with 5 question items. Descriptive analysis of locus of external control variables aims to group the results of respondents' answers to questionnaires related to the locus of external control with the highest value result ( $\max$ ) of 28 , the lowest value (min)of 6, the average value (mean) 19.50 and the standard deviation of 4,305 .

Locus of Internal Control

Locus of external control (X1.2) which had been measured using an online questionnaire or google form with 5 question items. This descriptive analysis of internal locus of control aims to group the results of respondents' answers to questionnaires related to the internal locus of control with the results resulting in the highest value (max) of 30 , the lowest value (min) of 13, the average value (mean) 22.85 and the standard deviation of 3,294.

Financial Attitude

Financial Attitude (X2) which had been measured using an online questionnaire or google form with 7 question items. Descriptive analysis of financial attitude aims to group the results of respondents' answers to questionnaires related to financial attitude with results resulting in the highest value (max)of 41 , the lowest value (min)of 17 , the average value (mean) 30.28 and standard deviation of 5,129 .

\section{Pocket Money}

Pocket Money (X3) which had been measured using an online questionnaire or google form with 1 question items. Descriptive analysis of pocket money aims to group the results of respondents' answers to questionnaires related to pocket money with the result of producing the highest value (max) of 4 , the lowest value (min) of 1 , the average value (mean) 2.26 and standard deviation of 0.909 .

Lifestyle

Lifestyle (X4) which had been measured using an online questionnaire or google form with 8 question items. Descriptive lifestyle analysis aims to group the results of respondents' answers to questionnaires related to lifestyle with results resulting in the highest value (max)of 48 , the lowest value (min)of 8 , the average value (mean) 28.38 and standard deviation of 8,268 .

\section{Classic Assumption Test}

Normality Test

Based on the Kolmogorov-Smirnov Test results, it can be seen that the significance value or Asymp. Sig. (2 tailed) of 0.200 . This value is more significant than $0.05(5 \%)$, so it can be concluded that the 


\section{Nominal: Barometer Riset Akuntansi dan Manajemen}

P-ISSN: 2303-2065 E-ISSN: 2502-5430

Volume 10 No 2 (2021)

residual data in this study were normally distributed.

Table 1. Normality Test Result

\begin{tabular}{cccc}
\hline Variable & Sig. & $\begin{array}{r}\text { Level } \\
\text { of Sig. }\end{array}$ & Description \\
\hline Residual & 0.200 & 0.05 & Normal \\
\hline
\end{tabular}

Multicollinearity Test

The multicollinearity test results show that all variables, namely the locus of external internal control, financial attitude, pocket money, and lifestyle have a tolerance value $>0.10$ and a VIF value < 10. So it can be concluded that these variables are free from multicollinearity.

Table 2. Multicollinearity Test Result

\begin{tabular}{|c|c|c|c|}
\hline Variable & Tolerance & VIF & Description \\
\hline $\begin{array}{l}\text { Locus of control } \\
\text { external }\end{array}$ & 0.841 & 1.150 & $\begin{array}{l}\text { No } \\
\text { Multicolerity }\end{array}$ \\
\hline $\begin{array}{l}\text { Locus of control } \\
\text { internal }\end{array}$ & 0.870 & 1.189 & $\begin{array}{l}\text { No } \\
\text { Multicolerity }\end{array}$ \\
\hline $\begin{array}{l}\text { Financial } \\
\text { attitude }\end{array}$ & 0.856 & 1.169 & $\begin{array}{l}\text { No } \\
\text { Multicolerity }\end{array}$ \\
\hline Pocket Money & 0.974 & 1.026 & $\begin{array}{l}\text { No } \\
\text { Multicolerity }\end{array}$ \\
\hline Lifestyle & 0.809 & 1.236 & $\begin{array}{l}\text { No } \\
\text { Multicolerity }\end{array}$ \\
\hline
\end{tabular}

\section{Linearity Test}

Based on, the liniearity test results through the signification value in deviation of linearity on each independent variable is greater than 0.05 then the research data can be said to be linear. Thus it can be concluded that the regression model in this study were linearity distributed.
Table 3. Linearity Test

\begin{tabular}{llll}
\hline Variable & $\begin{array}{l}\text { Sig. } \\
\text { (Deviation } \\
\text { from } \\
\text { Linearity) }\end{array}$ & Sig. & Desc. \\
\hline $\begin{array}{l}\text { E-money - } \\
\text { Locus of } \\
\text { control } \\
\text { external }\end{array}$ & 0.862 & 0.05 & Linear \\
$\begin{array}{l}\text { E-money - } \\
\begin{array}{l}\text { Locus of } \\
\text { control }\end{array}\end{array}$ & 0.251 & 0.05 & Linear \\
$\begin{array}{l}\text { internal } \\
\begin{array}{l}\text { E-money- } \\
\text { Financial } \\
\text { attitude }\end{array}\end{array}$ & 0.054 & 0.05 & Linear \\
$\begin{array}{l}\text { e-money - } \\
\text { Pocket Money } \\
\text { e-money - } \\
\text { Lifestyle }\end{array}$ & 0.895 & 0.05 & Linear \\
\hline
\end{tabular}

Heteroskedasticity Test

Based on, the heteroscedasticity test results through the Spearman Rank test show that the significance value of all independent variables is more significant than 0.05 . Thus it can be concluded that the regression model in this study does not occur heteroscedasticity disorders.

Table 4. Heteroscedasticity Test Result

\begin{tabular}{|c|c|c|c|}
\hline Variable & Sig & $\begin{array}{c}\text { Critical } \\
\text { Value }\end{array}$ & Description \\
\hline $\begin{array}{l}\text { Locus of } \\
\text { control } \\
\text { external }\end{array}$ & 0.593 & 0.05 & $\begin{array}{l}\text { No } \\
\text { Heteroskedastisity }\end{array}$ \\
\hline $\begin{array}{l}\text { Locus of } \\
\text { control } \\
\text { internal }\end{array}$ & 0.652 & 0.05 & $\begin{array}{l}\text { No } \\
\text { Heteroskedastisity }\end{array}$ \\
\hline $\begin{array}{l}\text { Financial } \\
\text { attitude }\end{array}$ & 0.896 & 0.05 & $\begin{array}{l}\text { No } \\
\text { Heteroskedastisity }\end{array}$ \\
\hline $\begin{array}{l}\text { Pocket } \\
\text { Money }\end{array}$ & 0.317 & 0.05 & $\begin{array}{l}\text { No } \\
\text { Heteroskedastisity }\end{array}$ \\
\hline Lifestyle & 0.137 & 0.05 & $\begin{array}{l}\text { No } \\
\text { Heteroskedastisity }\end{array}$ \\
\hline
\end{tabular}




\section{Hypothesis Test}

First Hypothesis Test (H1)

Based on table 5 below shows that the value of $t$ count variable locus of external control is greater than the value of t table (2.697>1.978) with a significance level below 0.05 which is 0.008 It is shown that $\mathrm{H} 1$ is supported, which states that the Locus of External Control variable has a positive influence on Use E-money.

In this case it is interpreted that the environment or influence of others on respondents of this study is high. $70 \%$ of digital payment users are at the age of 1530 years later use as well as the many discount and cash back programs as well as the influence of the environment and peers on the use of emoney in millennials (https://www.bbc.com/indonesia/indonesia -46624632 accessed on May 01, 2021 at 20:00). In addition, this research data was taken at the time of the COVID19 pandemic, where the government imposed Large-Scale Social Restrictions (PSBB) and suggested using e-money. This opinion is in line with the explanation by Bi Senior Deputy Governor Destry Damayanti who explained that electronic money is the top choice with $90 \%$ of users of the total transaction volume. This is due to largescale social restrictions (PSBB). So the high probability of using e-money can be caused by the influence of the Covid19 pandemic condition that is recommended to transact online. The results of this study are supported by Dindha Dwi Maharani Kusumastuti Research and previous research by Perry and Morris (2005)

\section{Second Hypotesis Test (H2)}

Based on table 5 below shows that the value of $t$ count variable locus of control internal $t$ count greater than $t$ table $(2.377>1.978)$ with positively count, significance 0.019 that more than 0.05 . It is shown that $\mathrm{H} 2$ is unsupported, which states that the Locus of Internal Control variable has a positive influence on Use E-money.

This result contrasts with the second hypothesis that the Locus of internal control negatively affects the use of e-money in students of university accounting courses in Yogyakarta. This means that accounting students at four universities in Yogyakarta have full control over themselves that they are able to take responsibility in making decisions on situations or events that have occurred. When students have full control of the events that occur then the intensity of e-money use will be suppressed or will decrease.

There are other factors that encourage students to use e-money, namely the Covid 19 pandemic that requires shopping and online transactions as a result of social distancing. This is in accordance with 
kaskuid article that explains that e-money and e-wallet become transaction solutions in times of pandemic with high efficiency, security, and reduce the presence of direct contact as a form of prevention of covid19 (https://www.kaskuid accessed on April 27, 2021, $03.00 \mathrm{pm})$. The results of this study were supported by Research Naila Al Kholilah and Almaidah Alta Oktavia Besri from the Management of the Islamic

Third Hypothesis Test (H3)

Based on table 5 below shows that the value of $t$ count variable financial attitude the calculated $t$ value is greater than $t$ table $(2,819>1,978)$ with a significance of 0.006 bigger than 0.05 positively distributed. It is shown that $\mathrm{H} 3$ is unsupported, which states that the Financial Attitude variable has a positive influence on Use E-money.

This means that accounting students at four universities in Yogyakarta have a good attitude and assessment on the issue so that they are able to make decisions on their finances. When students are able to assess an event then students will also be able to reduce the level of use of e-money because when using e-money excessively without thinking about the budget will cause financial problems in the future.

This pandemic makes people more enthusiastic in trading online and transacting online, the more products will be more varied offers such as discounts, vouchers in every purchase, and free shipping that makes it difficult for students to determine their judgment and attitude towards personal finances. This opinion corresponds to the article uploaded by Kompas.com. in the article, Center for Digital Society researcher Toni Seno explained that there has been a $30 \%$ increase in online shopping since the covid19 pandemic. This is due to the government's policy on social restrictions (https://www.kompas.com accessed on 27 April 2021, $03.00 \mathrm{pm}$ ). This research is also supported by research from Irine Herdjiono, Lady Angela Damanik and Ersha Amanah, Dr. Dadan Rahardian and Adila Iradianty

Fourth Hypothesis Test (H4)

Based on table 5 below shows that the value of $t$ count variable the calculated $t$ value is greater than $t$ table $(2.595>.1 .978)$ with significance 0.011 bigger than 0.05 . It is shown that $\mathrm{H} 4$ is supported, which states that the Pocket money variable has a positive influence on Use E-money.

This indicates that pocket money and e-money have a positive relationship, which means that when students have high pocket money they will tend to want a lot of things that often come out of the previous budget. This activity will make the student terlena and difficult to resist his wishes, as 
a result of pocket money will run out faster.

This statement is in accordance with an article by BBC News Indonesia on 24 December 2019 which states that electronic money will make money become more liquid, this means that it will be easier to use as a result of the ease of access (https://www.bbc.com accessed on 27 April 2021, $04.00 \mathrm{pm})$. This research is supported by the research of Dewi Kumalasari and Yohanes Hadi Soesilo and research by khasanah (2016)

Five Hypothesis Test (H5)

Based on table 5 below shows that the value of $\mathrm{t}$ count for lifestyle variables greater than $t$ table $(6.309>1.978)$ with a significance of 0.000. It is shown that H5 is supported, which states that the Lifestyle variable has a positive influence on Use Emoney.

Table 5. Hypotesis Result

\begin{tabular}{|c|c|c|c|}
\hline Model & $\mathbf{T}$ & T table & Sig \\
\hline (Constant) & & & 0.246 \\
\hline $\begin{array}{l}\text { Locus of } \\
\text { control } \\
\text { external }\end{array}$ & 2,697 & 1.978 & 0.008 \\
\hline $\begin{array}{l}\text { locus of } \\
\text { control } \\
\text { internal }\end{array}$ & 2,377 & 1.978 & 0.019 \\
\hline $\begin{array}{l}\text { Financial } \\
\text { attitude }\end{array}$ & 2,819 & 1.978 & 0.006 \\
\hline Pocket Money & 2,595 & 1.978 & 0.011 \\
\hline Lifestyle & 6.309 & 1.978 & 0.000 \\
\hline $\mathrm{R}$ & 0.696 & & \\
\hline r Square & 0.484 & & \\
\hline $\begin{array}{l}\begin{array}{l}\text { Adjusted } \\
\text { square }\end{array} \\
\end{array}$ & 0.464 & & \\
\hline
\end{tabular}

This can be interpreted that accounting students at four universities in Yogyakarta are millennials who are open minded to digital technology. Practical, fast, efficient, and safe are the main reasons students use e-money. Today e-money has become a lifestyle for the digital world of the world. The higher the student in addressing his lifestyle, the higher the use of e-money among the community. This statement is in accordance with an article from Tirto.id stating that e-money has become a lifestyle for millennials, with the ease with which students become addicted in utilizing it specifically as a generation that is literate of technology and the internet. But it does not apply to students with a cool attitude to lifestyle and tend to be zoned comfortably, the level of e-money use will tend to be low (https://www.tirto.id accessed on April 27, 2021, $04.00 \mathrm{pm})$. This research is supported by The Study of Ramadhani, Rianti Hikmah and in the research Arif Wicaksono Suharyanto and Endriana Pangestuti

\section{CONCLUSIONS AND SUGGESTIONS}

\section{Conclusion}

This study uses multiple regression analysis to prove the hypothesis. Based on the test results, the conclusions obtained are as follows: 
There is a positive influence between the locus of external control on the use of emoney in accounting students in Yogyakarta consisting of four public and private universities. The higher the level of student control on outside factors, the higher the student in using e-money.

There is a positive influence between the locus of internal control on the use of emoney in accounting students in Yogyakarta consisting of four public and private universities. Then the higher the control from within the student, the higher the use of e-money, but it should be if the student is able and confident to control the events from within him, then the lower the level of use of e-money. So the higher the self-control, the lower the intensity of emoney usage, while the lower the selfcontrol, the higher the use of e-money.

There is a positive influence between financial attitude on the use of e-money in accounting students in Yogyakarta consisting of four public and private universities. Then the higher the financial behavior that determines the financial attitude of students, the higher the use of emoney, but it should be when students are able to make financial decisions then the lower the level of use of e-money.

There is a positive influence between pocket money on the use of e-money in accounting students in Yogyakarta consisting of four public and private universities. Then the higher the pocket money owned by students, the higher the level of use of e-money, as well as the less pocket money owned, the lower the student in using e-money

There is a positive influence between financial attitude on the use of e-money in accounting students in Yogyakarta consisting of four public and private universities. So when students follow the trend and always open culture such as using e-money this will become a new habit and lifestyle and result in the high intensity of e-money use.

\section{Suggestion}

Based on the limitations of the research that has been described, the research advice for the future is as follows:

1. As a result of the physical distancing policy, the samples in this study can only be reached to four universities in Yogyakarta, therefore it is recommended to add research samples to all universities in Yogyakarta so that more and more respondents' numbers and quality so that the results will reflect the actual circumstances

2. This study uses an online questionnaire in the form of google form, for further research it is recommended to use interview techniques or offline questionnaires directly in the hope that 
the respondent's answer results will be more objective and avoid bias.

\section{REFERENCES}

Achmad Syafi"i \& Widijoko, G. (2015). Determinan Minat Individu Menggunakan Uang Elektronik : Pendekatan Modifikasi Technology Acceptance Model. Jurnal Ilmiah Mahasiswa FEB.

Adimaja, M. (2020, Juli 18). Transaksi Uang Elekteronik Naik Selama Pandemi Corona. From CNN Indonesia.

Adiyanti, A. I. (2015). Pengaruh Pendapatan, Manfaat, Kemudahan Pengguna, Daya Tarik Promosi, dan Kepercayaan terhadap Minat menggunakan layanan E-money. Jurnal Ilmu Ekonomi Universitas Brawijaya.

Affairs, I. P. (2014). How America Pays for College. Sallie Mae's National Study of College Students and Parents.

Alfianita, A. R. (2020). Pengaruh Gaya Kepemimpinan, Pengawasan dan Motivasi Kerja Terhadap Kinerja Karyawan Pamella Supermarket Yogyakarta. SKRIPSI.

Almaidah, A. O. (2018). Pengaruh Financial Attitude, Financial Knowladge dan Locus of Control terhadap Financial Management Behavior. SKRIPSI.

Ardiyanti, A. I. (2015). Pengaruh Pendapatan, Manfaat, Kemudahan Penggunaan Daya Tarik Promosi dan Kepercayaan terhadap Minat menggunakan E-money. Jurnal Ilmu Ekonomi Universitas Brawijaya.
As'ad, M. (2003). Psikologi Industri. Yogyakarta: Liberty.

Assyfa, L. N. (2020). Pengaruh Uang Saku, Gender dan Kemampuan Akademik Terhadap Perilaku Pengelolaan Keuangan Pribadi Mahasiswa Akuntansi dengan Literasi Keuangan Sebagai Variabel Intervening. Platform Riset Mahasiswa Akuntansi.

Damanik, I. H. (2016). Pengaruh Financial Attitude, Financial Knowladge, Parental Income Terhadap Financial Management Behavior. Jurnal Manajemen Teori dan Terapan, 9 (1), 226-241.

Dewi Kumalasari, Y. H. (2019). Pengaruh Literasi Keuangan, Modernitas Individu,Uang Saku dan Kontrol Diri terhadap Perilaku Konsumtif Mahasiswa Prodi S1 Pendirikan Ekonomi Angkatan Tahun 2016 Fakultas Ekonomi Universitas Negeri Malang. Jurnal Pendidikan Ekonomi.

Dewi, A. K. (2014). Pengaruh Locus of Control dan Motivasi Belajar Terhadap Prestasi Belajar Akuntansi Siswa Kelas XI IPS SMA Negeri 2 Sleman Tahun Ajaran 2013/2014. Skripsi.

Elliehausen, G. L. (2007). The Impact of Credit Counseling on Subsequent Borrower Behavior . Journal of Consumer Affairs , 1-28.

Ersha Amanah, D. R. (2016). Pengaruh Financial Knowladge, Financial Attitude dan External Locus of Control Terhadap Personal Financial Management Behavior pada Mahasiswa S1 Universitas Telkom. E-Proeeding of Management, 3(2), 1228-1235. 
Fadlillah, F. F. (2018, Maret 29). Sudah Saatnya Beralih ke E-money, Alat Pembayaran Zaman Now. From kemenkeu.go.id: www.kemenkeu.go.id

Ghozali, I. (2016). Aplikasi Analisis Multivariate dengan Program IBM SPSS 21 Update PLS Regresi. Semarang: Badan Penerbit Universitas Diponegoro.

Ghozali, I. (2017). Aplikasi Analisis Multivariate dengan Program IBM SPSS 21 Update PLS Regresi. From SPSS Indonesia: www.spssindonesia.com

Ghufron. M. N \& Risnawita, R. S. (2010). Teori Teori Psikologi. Yogyakarta: Ar-Ruzz Media.

Hadi, S. (2015). Statistika. Yogyakarta: Pustaka Belajar.

Hayhoe, C. L. (1999). Discriminating the Number of Credit Cards Held by College Students Using Credit Card and Money Attitudes. Journal of Economic Psychology, 20, 643-656.

Hidayati, S. (2006 : 7). Kajian Operasional E-money. Jakarta: Bank Indonesia.

Indonesia, B. (2014). Peraturan Bank Indonesia Penyempurnaan PBI GWM. Bank Indonesia.

Joelson, D. (2017). Locus of Control. Newsletter Articles.

Kanserina, D. (2015). Pengaruh Literasi Ekonomi dan Gaya Hidup terhadap Perilaku Konsumtif Mahasiswa Jurusan Pendidikan Ekonomi Undiksha 2015. Jurnal Pendidikan Ekonomi, 5(1).

Kasali. (1999). Management Public Relations. Jakarta: Penerbit Grafiti.
Khasanah, N. (2016). Pengaruh Uang Saku, Lingkungan Tempat Tinggal, dan Teman Sebaya terhadap Perilaku Konsumsi Mahasiswa S1 Pendidikan Ekonomi Angkatan 2014 Universitas Negeri Malang. Jurnal Skripsi.

Kreitner, R. d. (2001). Organizational Behavior. Irwin/McGraw-Hill.

Krisdiantoro, D. S. (2016). Pengaruh Iklan Online, Konformitas, dan Gaya Hidup Terhadap Perilaku Konsumtif . Journal Management .

Kusumastuti, D. D. (2016). Hubungan antara Locus of Control Eksternal dengan Perilaku Konsumtif pada Remaja Putri Tingkat Akhir. Naskah Publikasi.

Mahendra, I. (2018). Minat Individu Terhadap Penggunaan Mandiri ECash : Pendekatan Technology Acceptance Model. Jurnal Edik Informatika, 4(2).

Malik, A. (2020, Oktober 14). Transaksi Uang Elektronik Agustus Melesat Tembus Rp 17,23 Triliun, ini Data Historisnya. From Artikel Berita Ekonomi Terkini www.bareksa.com

Margareta Mona, J. K. (2015). Penggunaan Regresi Linier Berganda untuk Menganalisis Pendapatan Petani Kelapa. Studi Kasus Petani Kelapa di Desa Beo, Kecamatan Beo Kabupaten Talaud. Jurnal Matematika dan Aplikasi, 197.

Mutiara Dalin Siti Zulaika, A. L. (2020). Literasi Keuangan, Uang saku, Kontrol diri, dan Teman Sebaya Terhadap Perilaku Menabung Mahasiswa. Jurnal Pendidikan Ekonomi, 137-146. 
Naila Al Kholilah, I. (2013). Studi Financial Management Behavior pada Masyarakat Surabaya. Journal of Business and Banking, 69-80.

Pankow, D. (2012, August 4). Financial Values, Attitudes and Goals. From www.ag.ndsu.edu/agcomm/creativ e-commons

Putra, A. M. (2015). Indikator Keberhasilan Kinerja Individu dengan Locus of Control dan Kepribadian Sebagai Variabel Independen. Journal Indikator Keberhasilan Kinerja.

Raharjo, S. (2014). Cara Melakukan Analisis Regresi Multiples (Berganda) dengan SPSS. From SPSS Indonesia: www.spssindonesia.com

Raharjo, S. (2015). Cara Membuat Tabel Distribusi Frekuensi dan Statistik Dekriptif dengan SPSS. From SPSS Indonesia: www.spssindonesia.com

Ramadhani, R. H. (2019). Pengaruh Literasi Keuangan, Electronic Money, Gaya Hidup, dan Kontrol Diri Terhadap Perilaku Konsumtif Mahasiswa (Studi Kasus Mahasiswa Srata-1 Manajemen Universitas Sumatra Utara). Skripsi Departemen Manajemen.

Riadi, M. (2020, 08 April). Uang Elektronik atau Electronik Emoney. From Kajian Pustaka: www.kajianpustaka.com

Rifai, I. (2013). Hubungan Antara Locus of Control Internal dengan Kematangan Karir pada Siswa Kelas XI di SMK Muhammdiyah 1 Wates Tahun Pelajaran 2012/2013. Skripsi.
Rivai, V. (2007). Bank and Financial Institute Management. Jakarta: Raja Grafindo Persada.

Robbins, S. P. (2008). Perilaku Organisasi (Edisi 12 Jilid 1 ed.). Jakarta: Salemba Empat.

Rotter, J. B. (1966). Generalized Expentancies for Internal versus External Control of Reinforcement. Psychological Monographs, 80,1.

Rotter, J. B. (1972). Application of a Social Learning Theory of Personality. New York: Holt, Rinchart \& Winston.

Sathish., S. \&. (2012). Consumer Behavior and Lifestyle Marketing. International Journal of Marketing, Financial Services \& Management Research, 1(10).

Sayekti, W. N. (2013). Pengaruh Beasiswa PPA ( Peningkatan Prestasi Akademik) terhadap Prestasi Mahasiswa Fakultas Ekonomi Universitas Akademik. Platform Riset Mahasiswa Akuntansi.

Sekaran, U. d. (2017). Metode Penelitian untuk Bisnis: Pendekatan Pengembangan-Keahlian (Edisi 6 ed.). Jakarta Selatan 12610: Salemba Empat.

Silalahi, V. (2009). Hubungan Locus of Control dengan Perilaku Kesehatan pada Masyarakat Perdesaan. Skripsi Fakultas Psikologi Universitas Sumatra Utara.

Sugiyono. (2017). Metode Penelitian Kuantitatif, Kualitatif dan $R \& D$. Bandung: PT Alfabet.

Sugiyono, A. S. (2015). Cara Mudah Belajar SPSS \& Lisrel. Bandung: PT Alfabeta. 
Nominal: Barometer Riset Akuntansi dan Manajemen

P-ISSN: 2303-2065 E-ISSN: 2502-5430

Volume 10 No 2 (2021) 